\title{
Critical Analysis of the Level of Subjectivity and Objectivity While Reporting Kashmir Conflict: Comparative Study of Newspapers of Two Provinces of Jammu and Kashmir State
}

\author{
Pardeep Singh Bali ${ }^{*}$ \\ Reporter, Print Media, JK News Point, Srinagar, India
}

*Corresponding author: Pardeep Singh Bali, Reporter, Print Media, JK News Point, Srinagar, India, Tel: 0175 304 6554; E- mail: p.s.bali200@gmail.com Rec date: Mar 08, 2014, Acc date: Jul 28, 2014, Pub date: Jul 04, 2014

Copyright: (c) 2014 Bali PS. This is an open-access article distributed under the terms of the Creative Commons Attribution License, which permits unrestricted use, distribution, and reproduction in any medium, provided the original author and source are credited.

\begin{abstract}
In this research paper the level of subjectivity and objectivity adopted by journalists of different newspapers of the two provinces of the Jammu and Kashmir state has been analysed. This research paper emphasized upon the professionalism of the journalists of two provinces while catering to the readers of particular province. In this study it was found that in general reporters of both the provinces of the state are objective in their reporting, but it is also found that in certain cases Kashmir based reporters are subjective in their reporting, for example while covering Kashmir sentiments. They also use hard language against New Delhi, whereas Jammu based reporters are subjective only when it comes to defend Security forces and are also bitterly critical of Pakistan, accusing it as a sponsor of violence in Kashmir (including separatism). This paper found that newspaper of particular province serve to specific readers of their region, i.e. in Hindu majority province of Jammu, newspapers report as per the reading habits of Hindu readers and carries pro-India and anti-freedom reports. While as in Muslim majority province of Kashmir, newspapers carry anti-India and pro-freedom reports. Even senior journalists admitted that newspapers of both the provinces are doing justifiable job by serving what is expected from them.
\end{abstract}

Keywords: Conflict; Jammu and Kashmir; Print media; Reporter; Critical; Violence

\section{Introduction}

The media have a special relationship with conflict situations, external or internal. The reasons for such a relationship are two-fold: first, the conflict is acknowledged as being of major news value and, as such constitutes a major area of operation for the media across the world; second it is a matter of utmost public importance and interest because of its security implications. Moreover, media highlights ground situation of the conflict and educates masses about the social, political and economic condition of the area in conflict. However, it needs to be underscored that the parties in the conflict try, by hook or by crook, to use the media to further their respective interests and therefore, the media comes heavily under all sorts of undesirable pressures ranging to threats. In the conflict situation like Kashmir, media had to work under sheer pressure from both sides, i.e. militant organisations as well as security forces. Senior reporters claimed that during the peak time of conflict in Kashmir, many reporters were threatened by both militants and security forces to publish their reports. Freelance Journalist, Altaf Hussain, who was Bureau Chief BBC-Urdu shared that today it is not as much risky as it was some two decades back, when journalism was done on the tip of gun. Moreover, these days technology is developed manifold and so the process of communication is. Now, the things are not working in favour of journalists, as Kashmir has lost its news value and agencies are mushrooming, which covers events for all mediums. Therefore, apart from job security, there is no more risk to reporters in Kashmir. At the time of emergence of armed insurgency in Kashmir, the reporters had to be very meticulous while selecting their words, there was no scope for mistake, as the pressure was exerted from both militants as well as security forces. Both wanted to appear on the front page, therefore working was like hell in those conditions. There was no reporting as such, the papers carried whatever was thrown to them by various agencies. In the wake of this fear of being killed associated with this profession, many journalists quit their job, whereas many newspapers shut its publication. Even those who survived in this market avoided covering any conflict report and were wholly and solely reliant on press releases issued by these parties. Altaf Hussain further shared that many times reporters in those days had to kill their morality, professionalism and had to work under sheer pressure of threat from both, security forces as well as militants. Reporters were struggling to put facts, because no party was ready to hear truth, therefore journalists were the scapegoats. Furthermore, this profession was being cursed in Kashmir due to risk factor involved in it [1].

Media is more often held liable for indulging in sensationalism, exaggeration and manufacturing of stories, which has become a routine matter for some section of the media. The argument put forward by Editors Guild of India, in the Supreme Court of India, in favour of sensationalism has surprised many media practitioners and consumers. On April 3, 2012, the advocate for the guild proclaimed before the bench of the Supreme Court that "Sensationalism of media could not be stopped as it has worldwide phenomenon." In Jammu and Kashmir media has a tendency to blow up terrorists' activities and crime stories out of proportion and create fear psychosis among the public. "On April 7, 2012, I was in Jammu to attend a meeting in the Central University of Jammu. One of my friends from Kashmir University was to fly from Srinagar to Jammu on the same day. As I picked up the newspaper from the hotel room in the morning, I thought he might not be able to come to Jammu on that day. The Jammu edition of Hindustan Times carried a story on the front page with the headline: Ultras Attack Srinagar Airport, no causality. But, 
the intro read as: "suspected militants carried out a grenade attack at the Srinagar airport road, but there was no damage done in the explosion, officials said on Friday." When my friend arrived on time, he said he did not hear about the explosion though he lives very near to the airport road and was in the city on April 6. It has been observed that while covering such incidents media quite often fail to make a difference among Ultras, militants, extremists, Separatists and terrorists" [2].

\section{Overview of Kashmir Conflict}

Kashmir insurgency is one of the longest running conflicts in the world (BBC News, December 8, 2009). Kashmir has been at crossroads in relations between India and Pakistan since their independence from British rule in 1947. In the past 66 years, the two nuclear-capable countries have fought four wars, three of which have centered on Kashmir. The British left the Indian subcontinent in August 1947, but after its division into two nations - India and Pakistan. The basis of partition was religious - while India was found as a Hindu-majority state, Pakistan was envisioned by its founder, Mohammad Ali Jinnah, to be the home of the subcontinent's Muslims. Hindu-majority areas were designated parts of India while Muslim-majority areas were made parts of the new Pakistan. All provinces ruled by kings and princes were given a choice of acceding into either emerging state. The region of Kashmir (or the current Indian state called Jammu \& Kashmir) was a Muslim-majority province ruled by a Hindu king who delayed on the decision to join either India or Pakistan [3,4]. In October 1947, a tribal group in the southwestern part of Kashmir rebelled against the king and was provided support by the Pakistani army in the form of men and materials. When the rebels moved to the outskirts of Srinagar, the capital of the region, the king panicked and approached India for assistance. The Indian Prime Minister, Pandit Jawaharlal Nehru, agreed to provide military assistance on the condition that the king accede to India and the accession be approved by a popular leader and the people's representative, Sheikh Mohammad Abdullah.

Once the above two conditions were met, the Indian Army was airlifted into Kashmir. The two sides fought a bitter battle till the declaration of a United Nations sponsored ceasefire on January 1, 1949. By the time the war ended, the rebels supported by the Pakistani Army had managed to capture a third of the territory of the former princely state. The ceasefire line was declared the Line of Control (LoC) between the two nations and it has remained as such till this day. India referred the matter in 1948 to the United Nations Security Council, which passed several resolutions asking Kashmiri rebels and Pakistani forces to withdraw and mandating a free and fair plebiscite to determine the fate of Kashmir. Due to deep-rooted mistrust of each other, India and Pakistan have never carried out the terms of the U.N. resolution. The area captured by the rebels in the 1947 war is called "Azad" (Free) Kashmir by Pakistan and "Pakistan occupied Kashmir" (PoK) by India. The area under Indian control is called the state of Jammu \& Kashmir by India and Indian-occupied Kashmir by Pakistan and Kashmiri separatists [5].

The dispute about whether Kashmir should be a part of India or Pakistan is tied to the respective identities of the two nations. While on the one hand Pakistan contends that Kashmir should legitimately be a part of its territory, because the two-nation theory holds that Muslimmajority regions be a part of Pakistan, India insists that it cannot allow any part of its territory to be separated from it on the basis of religious affiliation because India was founded to be a pluralistic and multireligious nation [3]. Pakistan has consistently demanded that India conduct the UN-mandated plebiscite, a demand that India refuses to meet on the grounds that the plebiscite was on condition that Pakistan withdraw completely from the region, which it has not done to date. India also asserts that Kashmir is legitimately a part of its territory because the king chose to accede into India after the partition.

Another important reason why India refuses to let go of Kashmir is because it fears this will set off a domino effect and provide support to other regions in India that want to break off from the Indian union [6]. Tensions between India and Pakistan continued to simmer and reached a head several times, resulting in three more wars after the 1947 war - one in 1965, when Pakistan attacked India, believing it to be weakened by a humiliating defeat in the hands of China in 1962; and another in 1971, when India was instrumental in helping what was then East Pakistan to break away from Pakistan and become a separate nation -Bangladesh [3]. The third, although undeclared war was fought in 1999 in the Kargil sector in the upper reaches of the Himalayas in Kashmir. A decisive turn in the Kashmir dispute came in 1989, when Muslim extremists started an armed separatist movement in the Kashmir valley [4,6]. Their objective was a Kashmir independent of both India and Pakistan. After the start of the movement for self-rule, Hindus and Kashmiri Pandits, who were a minority in the Kashmir valley, left their homeland after their target killings. As civilian massacres became an everyday occurrence, the state government was dissolved and the Indian Army moved into the state to control the situation. Throughout the 1990s, the Indian Army continued to battle militant groups in Kashmir. India routinely accused Pakistan of supporting various terrorist groups in Kashmir and repeatedly asked Pakistan to refrain from doing so. On the other hand, Pakistan persistently accused India of denying Kashmiris the right to self-determination and of committing human rights violations [4]. Matters were further complicated and took a turn toward Islamic fundamentalism and "jihad" when the Afghanistan war ended in a Russian defeat in 1989 and Afghani mercenary fighters moved into Kashmir to support militant groups in the early 1990s. Moreover, the nuclearization of the subcontinent raised the profile of the Kashmir issue in the international arena, as western powers became increasingly alarmed at the possibility of border skirmishes escalating into a nuclear war between the two countries, notwithstanding India's offer of no first use of nuclear weapons. Ironically, according to New Delhi and Islamabad, overt acquisition of nuclear weapons had significantly reduced the likelihood of war between them [3].

Many Kashmiri youths in the late 1980s concluded that salvation lay in secession from India, which could be achieved only through an armed struggle. As a result, an armed movement was established which received massive support in Muslim dominated areas of Jammu and Kashmir. Apart from common Kashmiris, "government employees, the police forces, the academic intelligentsia and even some top bureaucrats supported the separatist slogans raised by the militants." The situation worsened to the extent that it became a question of re-establishing the Indian state's writ over Kashmir. The Kashmir conflict brought India and Pakistan to the brink of a nuclear catastrophe $[7,8]$.

\section{Special Status of Jammu and Kashmir}

It is often not realized that among the causes of Kashmir problem inclusion of plebiscite in the Instrument of Accession, reference of Kashmir to UN, halting Indian offensive when it was poised to drive out the invaders from Kashmir, Article 370 has played no less a part in preventing J\&K from becoming an integral part of the Indian Union. 
Not many people are aware as how and why this Article was formulated and included in the Indian Constitution despite grave misgivings of Sardar Patel and indeed a large number of the members of Congress Working Committee and Constituent Assembly.

Article 370 was worked out in late 1947 between Sheikh Abdullah, who had by then been appointed Prime Minister of J\&K by the Maharaja and Nehru, who kept the Kashmir portfolio with himself and kept Sardar Patel, the home minister, away from his legitimate function. Hence Nehru is answerable to all acts of commission and omission, consequences of which we are suffering till date as far as $\mathrm{J} \& \mathrm{~K}$ is concerned.

"Why should a state of the Indian Union have a special status? It conveys a wrong signal not only to Kashmiris but also to the separatists, Pakistan and indeed the international community that J\&K is still to become integral part of India, the sooner Article 370 is done away is better."

While it was Mountbatten who persuaded Nehru to take the J\&K issue to the UN, it was Sheikh Abdullah, who, driven by his ambition to be ruler of an independent Kashmir and his hatred for the Maharaja, persuaded Nehru to give special status to J\&K. Among his reasons were - occupation of one third of J\&K by Pakistan, reference to the UN and plebiscite. The most sinister aspect of proposed Article 370 was the provision that any changes could be brought about in it only by the concurrence of J\&K assembly. Nehru's promise that Article 370 was a temporary provision and will get eroded over a period of time has turned out to be a fantasy. The first thing that Sheikh Abdullah got done was to abolish hereditary monarchy and redesignate him as Sadar-e-Riyasat who was to be elected by the Assembly. The accession of J\&K State into Indian Union was approved by J\&K Assembly only in 1956.

Having finalized the text of Article 370 with Sheikh Abdullah, Nehru brought in Gopalaswamy Ayyangar, IAS, as a minister without portfolio to help him deal with Kashmir portfolio and plead the case of Article 370 in the Constituent Assembly. Gopalaswamy Ayyangar had been prime minister of Kashmir for six years with Maharaja Hari Singh. When Sardar Patel expressed his misgivings, this is what Nehru had to say on Dec 27, 1947.

"Gopalaswamy Ayyangar has been especially asked to help in Kashmir matters. Both for this reason and because of his intimate knowledge and experience of Kashmir, he had to be given full latitude. I really do not know where the States Ministry (Sardar Patel's ministry) comes into the picture except that it should be kept informed for the steps taken. All this was done at my instance and I do not propose to abdicate my functions in regard to matters for which I consider myself responsible. May I say that the manner of approach to Gopalaswamy was hardly in keeping with the courtesy due to a colleague."

It speaks volumes of Patel's loyalty to a colleague that despite his own and others misgivings, he managed to convince the members of Constituent Assembly and Congress Party Executive. But to V Shankar he said "Jawaharlal Royega".

The Sardar thereupon resigned and the matter fell in Gandhiji's lap to bring the two colleagues together. During this period, V Shankar, IAS was the personal secretary to Patel and had maintained a record of all events. It is clear from these records that Nehru finalized the draft of Article 370 along with Sheikh Abdullah without even informing Patel. Thereafter it fell to Gopalaswamy Ayyangar to get the draft passed in the Constituent Assembly discussions. The proposal was torn to pieces by the Constituent Assembly and also Congress Party Executive.

Nehru, who was abroad at the time, swallowed his pride and rang up Patel and requested him to get the Article 370 approved. V Shankar, in his record has described the meeting of the Congress Executive Committee "The meeting was one of the stormiest I have ever witnessed barring the party meeting which discussed the proposition relating to Rajaji becoming the first President of Indian Republic. The opinion in opposition to Gopalaswamy's formula was forcefully and even militantly expressed and the issue even brought in the sovereignty of the Constituent Assembly to draw up the Constitution without being tied down to the apron-strings of the Kashmir State Constituent Assembly. In such a situation even Maulana Azad was shouted down.

The Party was in uproar. The Sardar had to plead that because of the international complications, a provisional approach alone could be made leaving the question of final relationship to be worked out according to the exigencies of the situation and mutual feelings and confidence that would have been by then created. Once the Sardar had taken charge, all opposition to the draft was silenced" And how Nehru responded to this great act of loyalty on part of Sardar? On 24 July 1952, after Sardar was no more, Nehru made a detailed statement on Kashmir in the Parliament on slow integration of Kashmir into India Union and mentioned that "Sardar Patel was all the time dealing with these matters." Even Gopalaswamy Ayyangar was dismayed at this blatant lie and mentioned to V Shankar "It is an ill return to the Sardar for the magnanimity he had shown in accepting Panditji's point of view against his better judgment."

Article 370 has been the biggest impediment to integration of J\&K State into Indian Union. That it was incorporated in the Indian Constitution by the machination of two individuals-Shiekh Abdullah and Nehru is all the more regrettable. Nehru had to eat the humble pie when he had to arrest the Sheikh for his divisive and anti-national stance on 8 Aug 1953 but he did not let go of his concept of keeping J\&K a separate entity. In 1957, some top leaders of National Conference led by Mr. Qasim split the party and formed a group called Democratic National Conference (DNC).

Article 370, included in the Constitution on a temporary provision should have been gradually abrogated. This has not happened in sixty years.

It had abrogation of Article 370 on its agenda. Nehru would not brook any opposition to his policy of keeping $J \& \mathrm{~K}$ a separate entity. He told the leaders that a new threat (China) is emerging and it is an inopportune time to raise this issue and forced them to drop their demand. Nehru thereafter decided to withdraw the Kashmir conspiracy case against Sheikh Abdullah. This case had been going on since May 21, 1958. The formal orders however were issued by Government of India on 8 April 1964.

Why is Article 370 detrimental to the full integration of J\&K state into Indian Union. Firstly the Central Government can make laws only with concurrence of the State government, practically giving it the Veto power. Article 352 and 360 for declaration of national and financial emergency respectively cannot be applied in Kashmir. While a citizen of India has only Indian citizenship, J\&K citizens have two citizenships. Anti-Defection Law is not applicable to J\&K. No outsider can buy property in $\mathrm{J} \& \mathrm{~K}$ state. 
The beneficial laws such as Wealth Tax, Gift Tax \& Urban Land Ceiling Act and intermarriage with other Indian nationals do not operate in J\&K State. Even Article 356 under which President of India can impose his rule in any state cannot be enforced in J\&K without consent of the Governor who himself is an appointee of the President. State of J\&K can refuse building of any cantonment on any site or refuse to allot land for defence purposes.

Article 370 , included in the Constitution on a temporary provision should have been gradually abrogated. This has not happened in sixty years. In fact whenever someone mentions this, vested interests raise an outcry that legitimate rights of Kashmiris are being trampled upon. Stated agenda of National Conference is return to pre 1953 status.

\section{Article 370 of the Constitution of India Temporary Provisions with respect to the State of Jammu \& Kashmir}

\section{Notwithstanding anything in this constitution}

(a) The provisions of Article 238 shall not apply in relation to the State of Jammu \& Kashmir.

(b) The power of Parliament to make laws for the said state shall be limited to

(i) those matters in the Union List and the Concurrent List which in consultation with the Government of the State, are declared by the President to correspond to matters specified in the Instrument of Accession governing the accession of State to the Dominion of India as the matters with respect to which the Dominion Legislature may make laws for that State and

(ii) Such other matters in the Said Lists as, with the concurrence of the Government of the State, the President may, by order specify.

1. Explanation. For the purposes of this Article, the Government of the State means the person for the time being recognized by the President as Maharaja of Jammu \& Kashmir acting on the advice of the council of Ministers for the time being in office under the Maharaja's Proclamation dated the fifty day of March 1948.

(c) The provisions of Article (1) and of this Article shall apply in relation to this State;

(d) Such of the other provisions of this Constitution shall apply in relation to that State Subject to such exceptions and modifications as the President may by order specify;

Provided that no such order which related to the matters specified in the Instrument of Accession of the State referred to in paragraph (i) of sub clause (1) shall be issued except in consultation with the govt of the State.

Provided further that no such order which relates to matters other than those referred to in the last proceeding proviso shall be issued except with the concurrence of the Government of the State.

2. If the concurrence of the Government of the State referred to in para (ii) of Sub Clause (b) of Clause (1) be given before the Constituent Assembly for the purpose of framing the Constitution of the State is concerned. It shall be placed before such Assembly for such decision as it may take thereon.

3. Notwithstanding the anything in the foregoing provisions of the article, the President may, by public notification, declare that this
Article shall cease to be operative or shall be operative only with such exceptions and modifications and from such date as he may notify [9].

Provided that the recommendation of the Constituent Assembly of the State referred to in Clause (2) shall be necessary before the President issues such a notification [10].

Therefore, it is generally believed notion that Kashmir is one of the world's most critical and strategic locations and is considered as the most dangerous place on earth (BBC News, 2009), because of which it remained a 'pool of news' since its accession to India. Kashmir being the conflict zone, no doubt, has attracted attention of the international Press. Journalists here believe that there is pressure from many corners, which effects on the general reportage. Besides huge number of national and international media covering Kashmir conflict, more than 450 newspapers are published from Jammu and Kashmir province, respectively. A majority of the Journalists working in Kashmir are said to be professionals, having valid degrees, whereas Jammu lacks professionalism because of dearth of registered media institutes. Despite this fact, Jammu has more newspapers than that of Kashmir.

\section{Press in Jammu and Kashmir}

History of press in Jammu and Kashmir is more than hundred years old. As the world entered the 21st century, the press in Kashmir found itself in the whirlpool of dynamic changes as were the other media. The traditional role of media of transmitting and disseminating information to people has undergone a vast change in its presentation and contextualization. The democratization of information, existing political structures and the receding transnational boundaries makes it pertinent to place these changes in the context of their implications both for the individual as well as the policy makers. The role and importance of the press is all the more significant and critical in a place like Jammu and Kashmir state which has been caught in the imbroglio in the south Asian region on the world map for more than two decades. Incidentally, Budiya Bilas was the first newspaper of Jammu and Kashmir initiated by the government in 1856. Being an Urdu periodical, it served as a main tool of propaganda for the autocratic Maharaja who expostulated and dissuaded the publishing of newspapers as they were considered to be hazardous to the empire. Many small Urdu newspaper's Akbar-e-Aam, Khair-Kha-Kashmir, Guncha-Kashmir, Gulshan-e-Kashmir, Kashmir Darpan and Kashmir Gazette also came on the scene during that period but with little impact. They did some stories about the plight of the general public under the autocratic rule, but despite operating from outside the state, the editors of these newspapers could not cut much ice to highlight the problems of general public in Jammu and Kashmir State.

The path breaking journalism was started by Prem Nath Bazaz with Vitasta and Hamdard. Hamdard can be rightly called as the touch stone of real professional journalism from Jammu and Kashmir. Both reached the pinnacles of success and popularity due to intellectual eminence and astuteness. In a conflict situation like Kashmir, most of the truth has remained under the smoke screen of circumstances. It became very difficult for the vernacular press to report the truth when official spokesperson would say that a person was killed in cross fire and his family would say he was killed in cold blood [11]. In Kashmir, it is said that armed conflict turned boon for the growth of journalism. As key sectors like education, health and economy suffered, Kashmir's media miracle was set in motion and it (armed conflict) gave a huge platform to the journalists to grow $[12,13]$. 
The experience of terrorist organisations in controlling the media in Punjab encouraged similar organisations in Kashmir to take a leaf out of their book. Or maybe they had a common strategy relating to the media. In Kashmir too, some militant organisations succeeded in using the media to their ends. Some papers became their channels for communicating threats to people and those who had been threatened in their turn advertised their apologies through advertisements in these papers. Militant organisations also claimed responsibility for killings and kidnappings through press notes. When some editors resisted pressure from militants by warning that they would cease publication, attempts were made on the life of Sofi Ghulam Mohammad, editor, Srinagar Times on October 2, 1990. On November 4 the same year, a powerful explosion damaged the printing press of the daily Aftab. Most of the local papers closed down in protest. The widespread feeling outside Kashmir that the local press was on the side of the militants, was "uncharitable", according to the Narayanan committee. While quite a few papers did publish statements and advertisements of militant outfits, they did it under duress. "Given conditions of adequate safety of human lives, it is quite possible that these papers would be spreading the message of peace and harmony [14]."

\section{Significance}

Mass media plays a key role in today's conflict. Basically, their role can take two different and opposed forms. Either the media takes an active part in the conflict and performs a greater role in increasing violence, or it under-reports the event, thus helping in the reconciliation process leading to the resolution of the conflict. What role the media plays in a given conflict, and in the phases before and after, depends on a complex set of factors, including the relationship the media has with the actors in the conflict and the independence the media has to the power holders in society.

This study is intended to understand how newspapers in both provinces carry particular event, taking account of the prevailing situation. This research seeks to show how much contrary and biased treatment is given to similar event by newspapers of two different provinces of the state. Media play a crucial role in representing conflicts. Especially when media systems are located in states-at-war, or find themselves in (geographical or cultural) proximity of these states, the media's traditional claims towards objectivity, factuality and truth-speaking have to face severe pressures. In those conditions, the objectivity, fairness, authenticity and impartiality of the reporters are on stake and this research aims to analyse the magnitude of these elements in the reporting of journalists in two provinces of the state.

\section{Objective}

To critically analyse the level of objectivity and subjectivity while reporting events in conflict torn state of Kashmir.

\section{Hypothesis}

Reporters of Jammu province and Kashmir province are subjective in their reporting.

\section{Methodology}

'Content Analysis' method has been used to examine the course of conflict reporting. The sample consisted of four local English daily newspapers two from each province i.e. Jammu and Kashmir. The major events occurred during the time period of January 1, 2013 to August 31, 2013 have been analysed and interpreted.

The various parameters on which major incidents were selected included encounters, killing of civilians, militants and security forces, protests, hanging, communal clashes, minorities, external aggression and fidayeen attacks. However, interview method has also been used to get professional insight and historical account of the working of print media in Jammu and Kashmir [15]. The sample consisted of only four newspapers because the above selected newspapers have a professional team of reporters, editors and photo-journalists, which is not case with other newspapers of the state, who rely mostly on agencies.

The study analyses various aspects of different newspapers while covering similar event. The most significant analysing categories included content, space provided to particular event, language used, vocabulary, display and visual elements (Photographs, graphics and cartoon). The content of the selected newspapers from two different provinces of the state were compared to analyse their degree of subjectivity and objectivity. Moreover, interview of some senior journalists, who had worked across the length and breadth of the Kashmir conflict, was conducted to understand different phases of working of media in conflict.

\section{Sample Selection}

The four top notch English daily newspapers of the state were selected for current study, two from each province. Of the four, Daily Excelsior, Greater Kashmir and Kashmir Times are the oldest newspapers of the state, whereas fourth one Rising Kashmir is emerging English daily newspaper with growing readership. The Greater Kashmir-started publication in 1987 and Rising Kashmir in 2009 are popular local dailies of Kashmir province, whereas Daily Excelsior in 1965 and Kashmir Times launched in 1954 are two popular and most circulated local dailies of Jammu, respectively. These four newspapers have also been selected on the basis of circulation and huge readership.

The claimed circulation of Greater Kashmir, Rising Kashmir, Kashmir Times and Daily Excelsior are 75,000, 63,000, two million and 2,30499 respectively as per DAVP records (Figure 1).

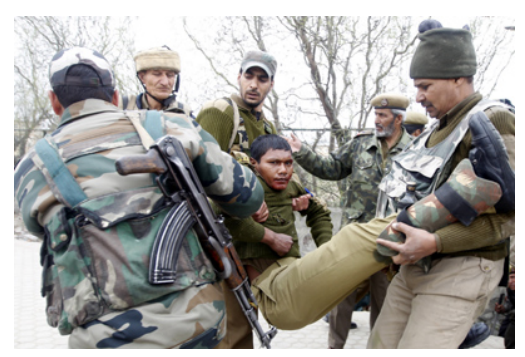

Figure 1: Image from Daily Excelsior, Jammu Showing security forces carrying wounded CRPF personnel away from the site of encounter in Bemina on March 14.

The vital factors that influence credibility of the above newspapers include their readership, circulation, sphere of influence and advertising. These newspapers are being used as the powerful medium to disseminate any centrally or state sponsored programme or scheme which inversely influences public opinion. Besides this, these 
Citation: Bali PS (2014) Critical Analysis of the Level of Subjectivity and Objectivity While Reporting Kashmir Conflict: Comparative Study of Newspapers of Two Provinces of Jammu and Kashmir State. J Mass Communicat Journalism 4: 213. doi:10.4172/2165-7912.1000213

Page 6 of 7

newspapers publish a number of articles on diverse topics and letterto-Editor, contributed by readers, which shows their public connection and concern. Moreover, large reader following on social media also makes their popularity significant.

\section{Discussion}

The present research paper was set out to know how print media covers Kashmir conflict. Content Analysis method was used to examine the course of conflict reporting; besides interview method was also used to get professional understanding of the media working in Jammu and Kashmir. The parameters on which major events within time period of January 1, 2013 to August 31, 2013 were selected included killings of civilians, militants and security forces, encounters, protests, hanging, minorities, communal clashes, social problems, external aggression and fidayeen attacks.

It is found that the reporters of Jammu province and Kashmir province are subjective while covering Kashmir. Kashmir based newspapers resort to subjectivity when they are reporting against security forces or when it's about Kashmir sentiments and concerning Muslims of Kashmir. For example, the subjectivity of the reporter of Rising Kashmir was apparent in the report of Afzal Guru hanging [16]. On day two, reporter lambasted Indian Judiciary for its decision of hanging Guru. The reporter also lobbed allegations against state chief minister for supporting the hanging [17].

However, Jammu based reporters resort to subjectivity, when it comes to defending wrong of the state or security forces. It is further found that Jammu based newspapers run contradictory report to that of Kashmir based newspapers. For example, in Gool area of Ramban district, where four people died and many others were injured in firing, Kashmir based newspapers Greater Kashmir and Rising Kashmir held BSF responsible for killing protesting civilians, whereas the Jammu based newspapers Daily Excelsior and Kashmir Times held civilians responsible for attacking BSF camp [18]. The reporters in Jammu also held local Maulvi (priest) responsible for the killing.

The subjectivity of the reporters of Kashmir province come fore while covering Indian Army. They avoid carrying much information regarding Army, but in case of militants, full coverage is provided. For example, Kashmir based newspapers under-report the events concerning killing of security forces, which is evident from the reports of the Haigam killing, Tral killing and Bemina killings, wherein Rising Kashmir and Greater Kashmir snubbed deaths of security forces, but have given huge space to the slain militants.

Contrary to this, Jammu based newspapers exaggerate the reports concerning security forces, which is evident from the reports of killing of Army by Pak soldiers at LoC, Haigam Killing and Bemina attack [19-22].

Moreover, in addition to the text of the events, which showed different line of ideology and policy of newspapers of two provinces of the state while covering conflict, the photographs also draw a great line of divide between journalism of two provinces while covering conflict. Out of the studied major events, photograph of some major events showed contrasting features as well as divide of thought process. For example, in a photograph of Bemina fidayeen attack in Srinagar [23-25], Greater Kashmir displayed body of a Militant being evacuated from the site of encounter by security men, which shows that paper gave importance to the slain militant. Whereas, Jammu based newspaper Daily Excelsior carried photograph of security forces carrying wounded CRPF personnel away from the site of encounter in Bemina, which makes it evident that security forces are significant for Jammu readers (Figure 2).

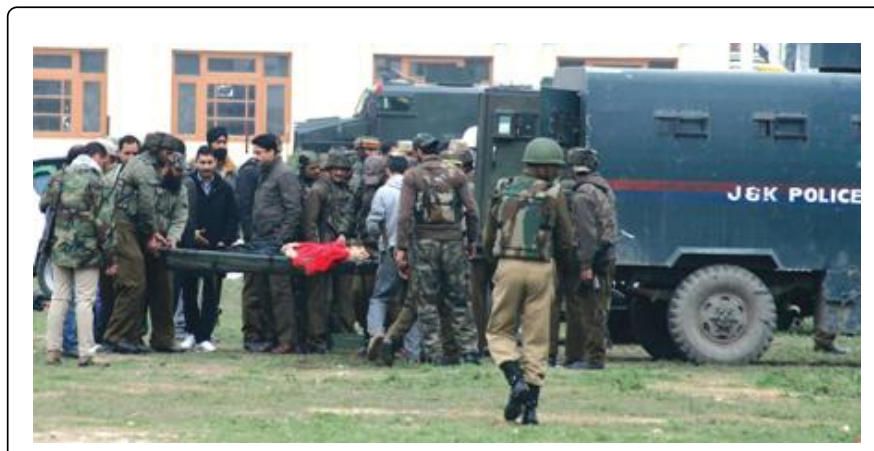

Figure 2: Image from Greater Kashmir, Kashmir Showing body of a militant being evacuated from the site of encounter in Bemina Srinagar on March 14

Similarly, newspapers of both the provinces carried photographs of Kishtwar violence differently. For example Kashmir based newspaper, Greater Kashmir carried photograph, showing Hindus protesting against the state government after rival communities clashed in Kishtwar, in Jammu (Figure 3). Whereas Jammu based newspaper [26,27], Daily Excelsior carried photograph, showing security personnel chase away protesters at a protest during curfew in Kishtwar, Jammu. However, in both these cases, the newspapers had taken pictures from agencies, but had doctored with its caption and usage (Figure 4).

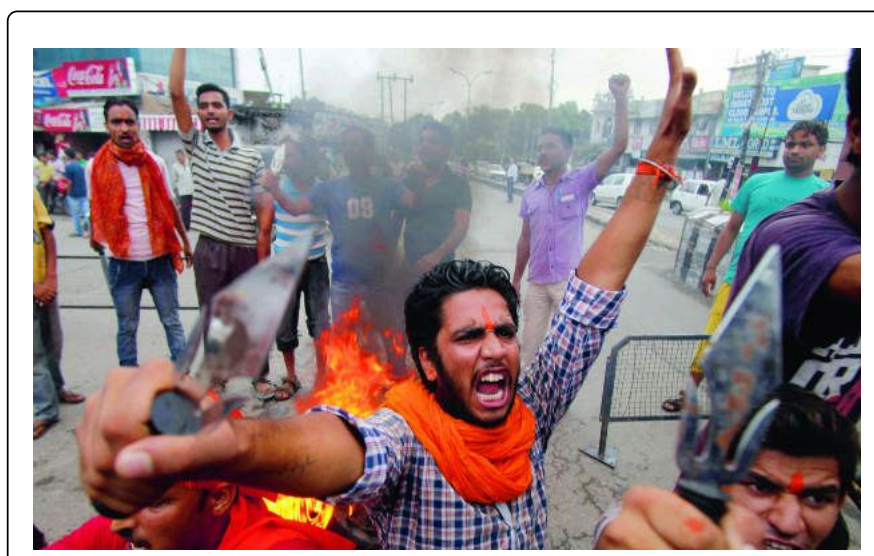

Figure 3: Image from Greater Kashmir, Jammu Showing Hindus protesting against the state government after rival communities clashed in Kishtwar, in Jammu on August 10.

Besides this, researcher has also observed the reporting of events in newspapers of both the provinces, as a reporter. Once while working for a Kashmir based newspaper, Rising Kashmir, researcher reported an event of army, wherein army hand-over full-facility stadium with gymnasium to people of Shopian, but to the surprise of researcher, next day news report was doctored and in the place of Army local administration was given credit.

Similarly, in Jammu, while working as a reporter for popular newspaper of Jammu, Early Times, researcher once reported atrocities 
Citation: Bali PS (2014) Critical Analysis of the Level of Subjectivity and Objectivity While Reporting Kashmir Conflict: Comparative Study of Newspapers of Two Provinces of Jammu and Kashmir State. J Mass Communicat Journalism 4: 213. doi:10.4172/2165-7912.1000213

Page 7 of 7

of CRPF in Kashmir, wherein CRPF personnel compelled young boys to lick text from street. But the report was dropped, saying that it will not have good impression of CRPF among readers.

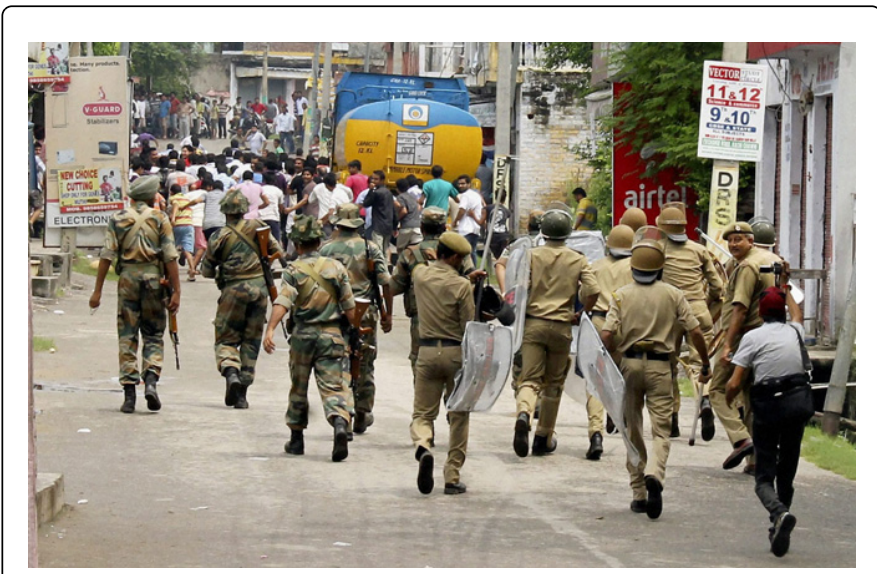

Figure 4: Image from Daily Excelsior, Showing security personnel chase away protesters at a protest during curfew in Kishtwar, Jammu on August 10.

Therefore, it is found that journalism in the two provinces of Jammu and Kashmir State is divided, biased, subjective and business oriented. Senior journalists also admit that the print media in Jammu and Kashmir is serving their commercial interest and cater to society as per their wishes to increase circulation.

\section{Acknowledgement}

The author would like to thank the faculty of the Department of Journalism and Mass Communication, Punjabi University Patiala for their support in carrying out this study. Furthermore, the authors appreciate the support and help from the members of MERC, University of Kashmir, Mr. Altaf Hussain, former Bureau Chief BBC, Kashmir, Ahmad Ali Fayaz, Bureau Chief, The Hindu, Aliya Bashir, Correspondent, The Dawn and others who made this work possible.

\section{References}

1. Yusuf S (2013) 2 students among three held for THREATENING Pragaash. Greater Kashmir.
2. Singh JL (2012) Media Ethics: Issues and Concerns, Punjabi University Patiala Publication Bureau.

3. Ganguly S (2001) Conflict unending. New York: Columbia University Press.

4. Dixit JN (2002) India-Pakistan in was \& peace. New York: Routledge.

5. Schofield V (2003) Kashmir in conflict: India, Pakistan and the unending war. London: I. B. Tauris \& Co. Ltd.

6. Cohen SP (2003) India, Pakistan and Kashmir. India as an emerging power, Frank Cass Publishers, Portland.

7. Hajni M (2009) The Kashmir conflict; A Kashmiri perspective.

8. Hajni M (2008) The Future of Kashmir. Swords and Ploughshares.

9. Shuchismita (2013) Cornered CM breaks down in assembly, assures full justice. Kashmir Times.

10. Thapliya S (2011) Article 370: The untold story, Indian Defence Review.

11. Khalid MZ (2002) Impact of Television upon urban youth of Srinagar city; A study of social change. Mphil thesis, Media Education Research Centre, University of Kashmir.

12. Parvez A (2011) INDIA: Kashmir's Media Miracle Feeds on Conflict, Inter Press Service.

13. Parvez MM (2013) BSF firing kills 4, injures 42 in Gool. Greater Kashmir.

14. Rai AK (2000) Conflict situations and the media: A critical look. 24: 585-601.

15. Suhail M (2013) 4 policemen killed in Hygam encounter. Rising Kashmir.

16. Mohiuddin A (2013) Afzal Guru Hanged. Rising Kashmir.

17. Anand A (2013) Guru Hanged, Buried in Tihar Jail. Greater Kashmir.

18. Rangrez S (2013) 6 killed 42 injured in Gool. Kashmir Times.

19. Ahmad H (2013) Militants strike at Haigam, kill 4 cops. Kashmir Times.

20. Ahmad S (2013) 4 Army men, militant killed in Tral Encounter. Kashmir Times.

21. Amjad S (2013) Pak soldiers cross LoC, Kill 2 Army men. Rising Kashmir.

22. Suhail M (2013) 4 soldiers gunned down in . Rising Kashmir.

23. Geelani SR (2013) Fidayeens are back: Gun down 5 CRPF men in Bemina Strike. Rising Kashmir.

24. Yousuf S (2013) 5 CRPF men, 2 militants killed in Bemina Fidayeen attack. Greater Kashmir.

25. Yousuf S (2013) 4 cops killed in ambush. Greater Kashmir.

26. Pargal S (2013) 2 killed, 63 injured, 100 shops burnt in Kishtwar. Daily Excelsior.

27. Sharma K (2013) 1 killed, over 30 injured in clashes at Kishtwar. Kashmir Times. 